\title{
Article \\ Geographic Scope and Real Estate Firm Performance during the COVID-19 Pandemic
}

\author{
Xiaoling Chu ${ }^{1}$, Chiuling $\mathrm{Lu}^{2,3}$ and Desmond Tsang ${ }^{4, *}$ \\ 1 Department of Real Estate \& Construction, University of Hong Kong, Hong Kong, China; \\ u3004703@connect.hku.hk \\ 2 School of Management, National Taiwan University, Taipei 10617, Taiwan; chiulinglu@ntu.edu.tw \\ 3 College of Finance, Takming University of Science and Technology, Taipei 11451, Taiwan \\ 4 Desautels Faculty of Management, McGill University, Montreal, QC H3A 1G5, Canada \\ * Correspondence: desmond.tsang@mcgill.ca
}

Citation: Chu, Xiaoling, Chiuling $\mathrm{Lu}$ and Desmond Tsang. 2021.

Geographic Scope and Real Estate Firm Performance during the COVID-19 Pandemic. Journal of Risk and Financial Management 14: 309. https://doi.org/10.3390/jrfm14070309

Academic Editor: Kim Hiang Liow

Received: 12 June 2021

Accepted: 29 June 2021

Published: 6 July 2021

Publisher's Note: MDPI stays neutral with regard to jurisdictional claims in published maps and institutional affiliations.

Copyright: (c) 2021 by the authors. Licensee MDPI, Basel, Switzerland. This article is an open access article distributed under the terms and conditions of the Creative Commons Attribution (CC BY) license (https:// creativecommons.org/licenses/by/ $4.0 /)$.
Abstract: This study examines the effect of geographic scope in mitigating the adverse impact of the COVID-19 pandemic in the real estate sector. Utilizing the Chinese setting over the two-month period in 2020 from the beginning of the outbreak to the successful containment of the spread of virus, we show that while the pandemic has negatively impacted real estate firm returns, firms with broader geographic scope and more geographically diversified property allocations have managed to better endure the crisis. We further find that firms with higher leverage report lower returns during the pandemic irrespective of their geographic scope, but larger firms can lessen the adverse impact of the pandemic only if they have adopted a more diversified strategy. Overall, our study provides novel evidence on the benefit of diversification by demonstrating the importance of geographic scope and diversification at times of crises. Specifically, we show corporate diversification could be especially useful to mitigate the negative stock market reactions resulting from the pandemic. Moreover, diversification could even become essential for larger firms that are expected by the market to be more diversified.

Keywords: geographic scope; diversification; real estate; firm performance; COVID-19; China

JEL Classifications: G01; G14; R30

\section{Introduction}

The COVID-19 pandemic has created havoc around the world. Since the discovery of the first cases in December 2019, the virus initially spread, with cases reported and hastily rising in China, then rapidly spread to the world (Pettersson et al. 2020). The pandemic has caused a global panic, resulting in one of the biggest stock market crashes in history. Over the month of March 2020, the global stock markets declined by over 30\%. Singh et al. (2020) show that after the COVID-19 outbreak, both developed and developing countries reported negative abnormal stock returns, that ranged from $-0.7 \%$ to $-42.69 \%$, resulting from the varying increasing numbers of COVID-19 positive cases in different countries. In the U.S., the stock market crash associated with COVID-19 surpassed the global financial crisis (GFC) in 2008 and the Great Depression in 1933 and was ranked the third largest after the Great Crash in 1929 and Black Monday in 1987 (Baker et al. 2020). As for China, Sun et al. (2021) show that the COVID-19 outbreak caused some of the largest negative returns in the Chinese stock market, up until the end of March 2020 where the spread of the virus was eventually contained in the country.

In this study, we examine how geographic scope and diversification enable firms to better weather the storm brought upon by the COVID-19 pandemic. Unlike other crises such as the GFC, the COVID-19 pandemic is location-specific due to varying degrees of 
positive cases in different regions and vastly different government responses and interventions to contain the spread of the virus and to stimulate the economy. Hence, we conjecture that increasing the geographic scope of a firm has a significant bearing on how well the firm can survive through the pandemic. Prior literature in management and finance has long argued that diversification has various benefits but has also noted its associated agency and coordination costs. Earlier studies such as Lewellen (1971), Grant et al. (1988), and Stein (1997) show that diversification increases firm profitability due to economies of scale and access to resources and clientele. Delios and Beamish (1999) demonstrate that the benefit of diversification is due to higher market power and reduced input costs. However, Markides (1995) documents a trend of firm restructuring with less diversified strategies because of their associated costs. Ayers et al. (2011) show that cost of monitoring is higher for more remote firm locations, implying higher agency costs for diversified firms. Hashai (2015) demonstrates that the presence of coordination costs could outweigh diversification benefit. Empirical research on the relationship of geographic scope and diversification and firm performance seems to also provide inconclusive findings. On the one hand, Tallman and Li (1996) provide some early empirical evidence that shows minimal performance differences across firms with different levels of international diversity. Berger and Ofek (1995) document a 13\% to 15\% average value loss from diversification, and they find that overinvestment and cross-subsidization contribute to the value loss. Similarly, Denis et al. (2002) show global diversification leads to a valuation discount. Gao et al. (2008) also show a diversification discount, and they attribute their findings to higher agency costs and weaker governance for diversified firms. Palich et al. (2000), on the other hand, following three decades of research in a meta-analysis, show that moderate levels of diversification outperform either limited or extensive diversification. Qian et al. $(2008,2010)$ hypothesize that the relationship of diversification and firm performance is nonlinear, and they find that diversification is value-enhancing to a certain level, then its value becomes negative. Santalo and Becerra (2008) show that diversification could be beneficial in some industries, while there exist diversification discounts in others. Chakrabarti et al. (2007) also show the benefit of diversification, which depends on a firm's institutional environment. A recent working paper by Chu et al. (2021) shows that in China, there is diversification benefit pertaining to the less developed regions due to lower market competition, but diversification benefit disappears in superstar cities such as Beijing and Shanghai. Overall, these studies demonstrate that the benefit of diversification is not absolute, and it depends on the specific context of the firm operating environment.

To examine our hypothesis of how geographic scope and diversification affect firm performance during the COVID-19 period, we empirically examined stock market performance of a sample of Chinese real estate firms over the peak period of COVID-19 in China, from the beginning of February to the end of March in 2020. As shown in Figure 1a, this period also coincided with the lockdown of the Hubei province and the subsequent lifting of Wuhan lockdown when the virus spread was successfully contained in China. Figure $1 \mathrm{~b}$ displays value-weighted cumulative returns for the Chinese A-share stock market (i.e., firms that trade on the Shanghai Stock Exchange and the Shenzhen Stock Exchange), showing that it had the sharpest decline during this period. We first investigated in our baseline analysis how the pandemic affects firm values by comparing weekly stock returns of our sample firms during the COVID-19 period with the benchmark period of November to December in 2019, before the first reported case of COVID-19 in China and in the world. Following Ding et al. (2021), we used the growth rate of the cumulative number of confirmed COVID-19 cases and active cases as a measure of the exposure to the pandemic. We adopted a multivariate regression framework with fixed effect and control for firm fundamentals before the pandemic to capture their ex-ante influences on firms' resilience to the crisis and to minimize endogeneity bias (Ding et al. 2021; Fahlenbrach et al. 2020; Hu et al. 2021; Li et al. 2020). Consistent with the expectation of the pandemic, we documented a significant negative market reaction to the growth of COVID-19 cases and active cases over the sample period. 


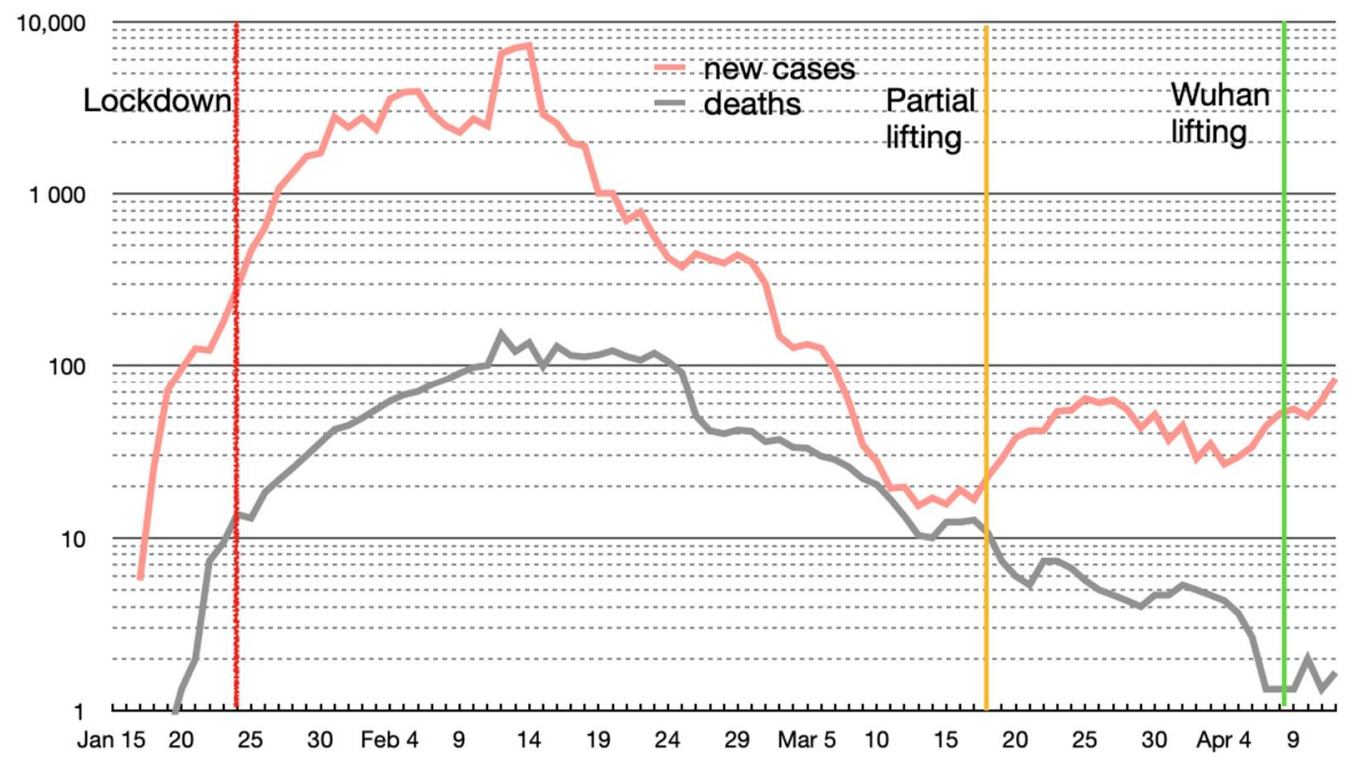

(a)

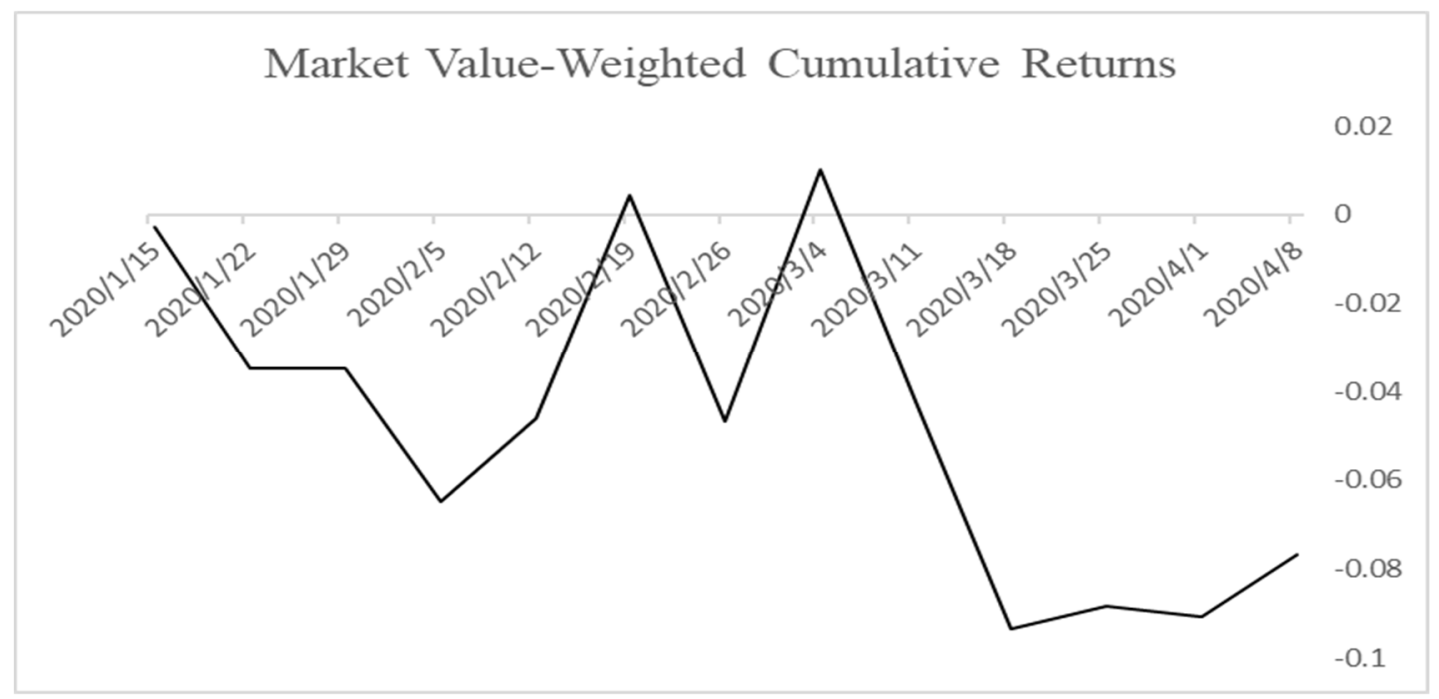

(b)

Figure 1. (a) COVID-19 cases and deaths in China with Hubei lockdown. Source: Wikimedia Commons; (b) market value-weighted cumulative returns. Source: CSMAR database.

We next examined in our main analysis whether geographic scope matters for firm values at times of health crisis. We measured geographic scope by the natural logarithm of the number of cities where a real estate firm has operations (Chu et al. 2021; Gao et al. 2008; Shi et al. 2015). Our empirical findings suggest a positive interactive effect between geographic scope and COVID-19 exposure, implying that broader geographic scope has mitigated the adverse stock market impact of the COVID-19 pandemic. In other words, our findings indicate that firms with a more geographically diversified portfolio have been perceived by investors to be better able to weather through the COVID-19 pandemic. The findings coincide with the existing literature that emphasizes the benefit of diversification in specific circumstances (e.g., Chakrabarti et al. 2007; Santalo and Becerra 2008).

We next conducted heterogenous analysis to evaluate the impact of firm characteristics on the mitigating effect of geographic scope on real estate firm returns during the COVID19 period. Our findings show firms with higher leverage report lower returns during the pandemic irrespective of their geographic scope, but larger firms could lessen the adverse impact of the pandemic only when they have broader geographic scope. The findings 
in the heterogenous analysis imply that larger firms could be more seriously exposed to the pandemic when they are geographically focused, but they could moderate such negative effects of the crisis when they adopt a more diversified property allocation strategy. However, geographic scope does not seem to matter in lessening the negative impact of COVID-19 for highly leveraged firms, since these firms tend to have higher bankruptcy risk, and there is a significant concern that they would not survive through the pandemic crisis (Ding et al. 2021).

In robustness analysis, we extended our analysis to cover the recovery period (from April to May in 2020). We show that our results remain intact during the COVID-19 period when compared to this alternative benchmark period. We also performed an additional analysis to confirm that our findings are robust to an alternative return definition of abnormal return using the market model.

We utilized the Chinese setting to examine whether geographic scope affects firm values during the COVID-19 pandemic because it allowed us to apply a clean event of the pandemic. Due to the Chinese government's effective response to the health crisis (Li et al. 2021), the pandemic was successfully contained by early April and there was little relapse unlike other countries or jurisdictions. Moreover, focusing on a single country enabled us to alleviate concerns of cross-country differences in international diversification studies (Hitt et al. 2006). Specifically, we focused on Chinese real estate firms, as the location-specific nature of property assets allow us to have clean identification of their geographic scope and diversification strategies. Furthermore, in China, most of these real estate firms focus on developing residential and commercial properties; hence, the industry is relatively homogenous as compared to its U.S. counterpart that focuses on different types of properties. Moreover, real estate developers may have a shorter investment horizon than passive investment vehicles such as REITs, and therefore they could be more affected by the short-term market turbulence brought upon by the pandemic.

Overall, our study contributes to the literature in the following ways. First, we add to the general literature on the debate of the benefits of versus discount on geographic scope and diversification. Our findings also bear interesting contrast to the existing real estate literature, which predominantly reports little benefit of diversification (e.g., Boer et al. 2005; Campbell et al. 2003; Capozza and Seguin 1998; Eichholtz et al. 1995). Cronqvist et al. (2001) attribute these findings to agency cost concerns. While some recent studies argue diversification could be beneficial under better monitoring, resulting in lower costs of debt (Demirci et al. 2018) and higher firm values when firms are more transparent (Feng et al. 2019), with more institutional following (Hartzell et al. 2014; Ling et al. 2021), and with lower distance of properties to the headquarters (Milcheva et al. 2020), we show that diversification could also provide benefits for real estate firms under an adverse economic environment brought upon by an unprecedented health crisis. We attribute the findings to geographic scope, which lowers the risks faced by real estate firms when the pandemic presents varying degrees of damage to different regions. In so doing, our study contributes to existing literature on the benefit of diversification by providing novel evidence of a diversified portfolio strategy that could be useful in aiding firms to better endure the COVID-19 crisis that has impacted varying regions differently.

Second, we add to the growing literature that investigates the impact of the current pandemic on real estate equities and more broadly on the real estate market. Ling et al. (2020) examined the U.S. market and established a negative relationship between commercial real estate firm returns and portfolio exposure to the growth in COVID-19 cases. Akinsomi (2020) shows that while most REITs suffer significant decreases in firm values during the pandemic, there exists a flight-to-quality phenomenon to REIT types that are not as adversely affected. Xie and Milcheva (2020) examine the effect of distance on COVID-19 cases on real estate firm returns. They demonstrate a significantly negative effect of the COVID-19 pandemic, as firms closer to the COVID-19 cases suffer more in their performances. In the real estate market, studies show the pandemic has little negative effect on U.S. residential properties (D'Lima et al. 2020; Zhao 2020). Van et al. (2020) examined the 
U.S. commercial real estate market and observed decreases only in market liquidity but not price. Huang et al. (2020) also obtain similar findings for the Chinese housing market that the adverse impact of price is minimal while transaction volume falls. Similarly, Qian et al. (2021) show significant price declines in Chinese regions with a high number of confirmed COVID-19 cases. Lastly, Yang and Zhou (2021) show a positive impact of COVID-19 in certain second and third-tier Chinese cities in the housing market, and they attribute their findings to an increase in demand of residential space due to families staying together during the pandemic. Our study adds to this growing literature by suggesting, given a geographically diverse underlying asset base, that diversified real estate firms are not as impacted as geographically focused firms by the severity of COVID-19 cases concentrated in specific regions. As a result, these diversifying firms are better able to mitigate the negative market reaction documented in the real estate equity market.

Third, our study contributes to the emerging literature related to examining the capital market consequences of the current health pandemic (e.g., Alfaro et al. 2020; Baker et al. 2020; Chen et al. 2020; Fahlenbrach et al. 2020; Schoenfeld 2020; Shehzad et al. 2020). In particular, we add to the literature examining the corporate strategies that enable firms to better navigate through the pandemic crisis (e.g., Pagano et al. 2020; Papanikolaou and Schmidt 2020; Ramelli and Wagner 2020). Acharya and Steffen (2020) and Ding et al. (2020) both look at the impact of various firm fundamentals, such as cash holdings and leverage policies, in mitigating the impact of the crisis. Other studies relate firm performance during the COVID-19 period to their environmental ratings (Albuquerque et al. 2020), firm-level exposure (Hassan et al. 2020), and corporate culture (Li et al. 2020). Our study specifically relates to studies investigating the impact of the current pandemic on the Chinese stock market. For instance, Sun et al. (2021) show an overall negative impact of the pandemic on Chinese stock market, and this could be explained by stronger correlation between investor sentiment and stock returns in the COVID-19 period. Ding et al. (2020) examined stock market responses in China with two events, and they showed that firms with Hubei exposure earned significantly lower returns after the lockdown of the province than those without the exposure. Finally, Shan and Tang (2020) used survey data on employee satisfaction in China to show that firms with higher employee satisfaction were associated with better stock price performance during the pandemic. To the best of our knowledge, our study is the first to examine the usefulness of geographic scope and diversification strategies during the current pandemic.

The remainder of this paper proceeds as follows. Section 2 describes the sample selection process and presents summary statistics. Section 3 presents our research design, followed by main empirical findings on the association between COVID-19, geographic scope, and firm value. Section 4 reports empirical results of heterogenous analysis and robustness checks. We offer discussions and concluding remarks in Section 5.

\section{Sample Selection and Descriptive Statistics}

\subsection{Sample Selection}

The sample of this study consists of real estate firms listed in the Chinese A-share stock market that trade on the Shanghai Stock Exchange and the Shenzhen Stock Exchange. Similarly to Chu et al. (2021), we excluded firms that are subject to special treatment (ST), firms that are in suspension of trading during the sample period, and firms that do not report their property locations in their financial statements. The study involved hand-collecting information on the geographic locations of properties for these firms from the note disclosures of the annual financial statements. Specifically, we identified the cities in which firms have operations, and this process generated 70 real estate firms in our final sample. We obtained stock price and other firm data of these sample firms from the China Stock Market and Accounting Research (CSMAR) database.

We measured firm value, our dependent variable, Weekly Return, using weekly stock returns. The variable is calculated by dividend-adjusted closing prices on the last trading day of the week on every Friday. Alternatively, we also calculated abnormal returns, Abnor- 
mal Return, to account for the risk-adjusted performance of sample firms. Abnormal Return was measured as the weekly stock returns of a firm minus its beta times value-weighted market returns for Chinese A-share stocks from the market model (e.g., Lins et al. 2017).

The outbreak of COVID-19 in China started from the middle of January in 2020. It was then followed by the Chinese New Year on 25 January 2020, with the Chinese stock market being on hiatus. Thereafter, the Chinese government imposed a strict lockdown of its Hubei province, with other pandemic measures, such as travel restrictions, implemented throughout the whole country (Li et al. 2021). Since then, China went through a first wave of rising COVID-19 cases and deaths, before the numbers finally came back down with the lockdown measures partially and fully lifted towards the end of March and the beginning of April, respectively. To provide a clear identification of the COVID-19 period, we restricted our test sample period to one week after the January 25 lockdown and one week before the full lift of the lockdown measures at the beginning of April (i.e., the test sample period covers the first week of February to the last week of March). Correspondingly, we needed to select a benchmark period that was not subject to any health concern of the pandemic. We therefore selected the two-month period from the beginning of November to the end of December in 2019, before news of the first reported cases of COVID-19 broke around the end of the calendar year. In robustness analysis, we also adopted the recovery period from April to May in 2020 as a benchmark period.

To measure exposure to the COVID-19 pandemic, we obtained data from the Coronavirus COVID-19 Global Cases Database developed by the Johns Hopkins University (JHU). Following Ding et al. (2021), we adopted a growth-based measure of COVID-19 exposure, since firm returns should be affected by changing severity of the COVID-19 pandemic throughout the period. Our measure of COVID19 Case is the growth rate of the cumulative number of confirmed cases in each week, measured from Saturday to Friday to correspond to our measures of firm returns. Specifically, the weekly growth rate of confirmed COVID-19 cases is measured as:

$$
\text { COVID19 } \text { Case }_{t}=\ln \left(1+\text { Cumulative Cases }_{t}\right)-\ln \left(1+{\text { Cumulative } \left.\text { Cases }_{t-1}\right)}\right.
$$

where Cumulative Case is the cumulative number of confirmed cases as of Friday at the end of each week.

Alternatively, the severity of the pandemic depends not only on the growth of COVID19 cases but also on how many active cases remain after deaths and recoveries. We therefore adopted another measure from Ding et al. (2021), COVID19 Active Case, measured as the weekly growth rate of active COVID-19 cases. Specifically, it is measured by:

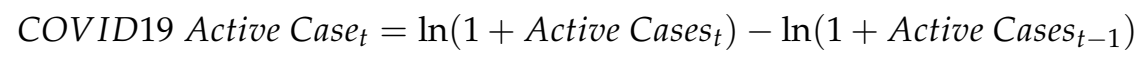

where Active Case is equal to Cumulative Case minus recoveries and death.

Ideally, geographic scope should be value weighted according to how much, instead of where, a firm diversifies it assets. However, detailed information on the individual valuation of property assets is voluntarily disclosed and unavailable for most of our sample firms. We therefore measured geographic scope, Geographic_Scope, by the number of cities where a firm has operations (Chu et al. 2021; Gao et al. 2008; Shi et al. 2015). Specifically, Geographic Scope is the natural logarithm of the number of cities where a real estate firm has operations measured at the end of 2019.

Given that Wuhan was considered as the epicenter of the pandemic in China and that Xie and Milcheva (2020) show that proximity to COVID-19 cases has a significantly negative impact on real estate firm returns, we included Distance, measured as the natural logarithm of the distance (in kilometers) between corporate headquarters location and the centroid of Wuhan, as a control variable. We included firm fundamentals that affect stock returns, which include Size, Leverage, and Cash. Following prior studies (e.g., Ding et al. 2021; Fahlenbrach et al. 2020; Li et al. 2020), we measured these firm characteristics before the pandemic at the end of 2019 to capture the ex-ante influences of these variables on firms' 
resilience to COVID-19 and to minimize endogeneity bias. We include in Appendix A detailed definitions of all variables used in the study.

\subsection{Descriptive Statistics and Correlations}

Our total sample has 1260 weekly observations over the test sample and the benchmark periods. Table 1, Panel A, presents descriptive statistics of the variables used in empirical analyses. Weekly Return and Abnormal Return are both slightly positive with respective means of $0.08 \%$ and $0.20 \%$, as we have included both the benchmark and the test sample periods in our analysis. Growth rates of COVID-19 cases and active cases both have a mean of 0.12. Geographic Scope has a mean of natural logarithm of 2.02, implying Chinese real estate firms diversify by allocating their property assets to about 7.54 cities on average. Average distance to Wuhan (in natural logarithm form) is 6.67. Firm size has a mean of 24.31 (in natural logarithm form). Lastly, our sample firms report an average leverage ratio of $69 \%$ and cash holdings of $13 \%$.

Table 1. Descriptive statistics and correlations. (a) Descriptive statistics; (b) correlations.

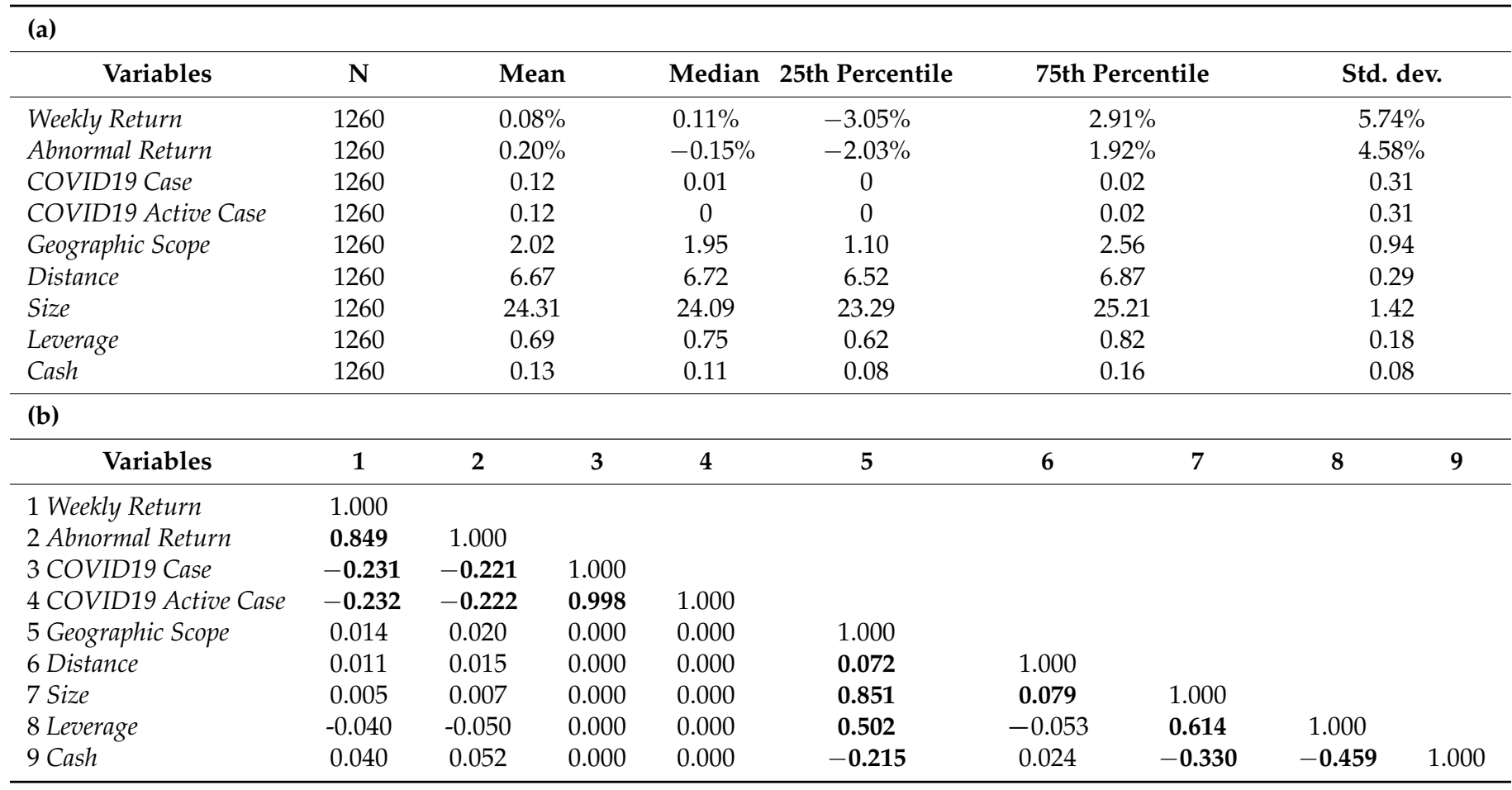

This table provides descriptive statistics and Pearson correlations for the sample observations of the variables used in the empirical tests. Bold figures in (b) denote significance at the $1 \%$ level. Variable definitions are provided in Appendix A.

Table 1, Panel B, presents Pearson correlation matrix of the main variables. We find that stock returns for real estate firms are significantly negatively associated with COVID-19 cases, while stock returns are insignificantly associated with geographic scope.

\section{Research Design and Empirical Findings}

\subsection{Research Design}

For our baseline analysis of the effect of the COVID-19 pandemic on real estate firm returns, we ran regression analysis with property type fixed effect for the following specifications:

$$
\begin{gathered}
\text { Weekly Return }=\alpha+\beta_{1} \text { COVID19 Case }+\beta_{2} \text { Distance }+\beta_{3} \text { Size }+\beta_{4} \text { Leverage }+\beta_{5} \text { Cash }+\varepsilon \\
\text { Weekly Return }=\alpha+\beta_{1} \text { COVID19 Active Case }+\beta_{2} \text { Distance }+\beta_{3} \text { Size }+\beta_{4} \text { Leverage }+\beta_{5} \text { Cash }+\varepsilon
\end{gathered}
$$


Our variables of interest were COVID19 Case and COVID19 Active Case, which measured exposure to the COVID-19 pandemic in terms of the growth of COVID-19 cases in China. We expected negative and significant coefficients for $\beta_{1}$ given the adverse impact brought upon by COVID-19 to the global stock markets.

We next examined our main research question on how geographic scope mitigates the impact of COVID-19 on real estate firm returns. We expected that geographic scope could allow real estate firms to diversify their risks by not concentrating their exposure to a single city. This is especially important during the COVID-19 pandemic, where some regions and cities in China (e.g., Hubei province and Wuhan) were more seriously affected by the pandemic than the others. Moreover, the spread of the virus had created huge uncertainty and thereby affected investor sentiment in the Chinese stock market (Sun et al. 2021). Hence, even for a firm with little exposure to the hard-hit cities of COVID-19, investors might still respond more favorably to firms with broader geographic scope. This is because investors would have less perceived risk of COVID-19 for firms that are diversified, since these firms bear less downside risk of concentrating in specific regions should the COVID-19 situation in these regions worsen. To test our hypothesis, we ran regression analysis with property type fixed effect for the following specifications:

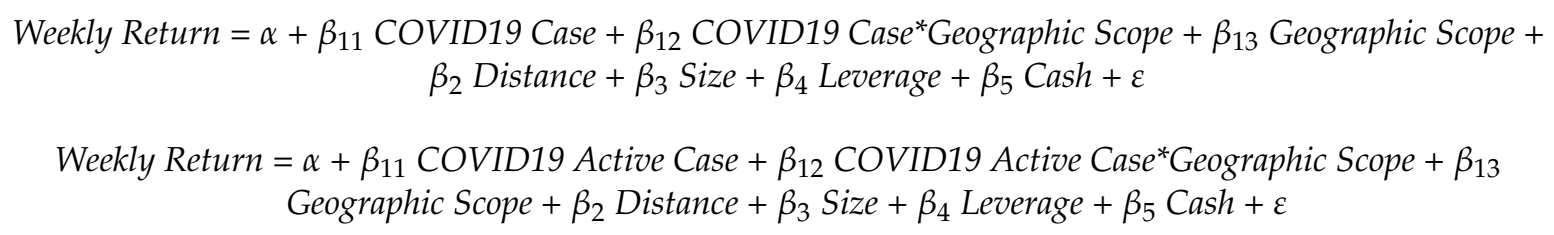

Our variables of interest are the interaction terms of COVID19 Case (COVID19 Active Case) with Geographic Scope. If geographic scope mitigates the adverse impact of the COVID-19 pandemic, we expect positive and significant coefficients for $\beta_{12}$.

\subsection{Empirical Findings}

Table 2 presents the estimation results of specifications (1) and (2), with the first and second columns showing the impact of the COVID-19 variables COVID19 Case and COVID19 Active Case on real estate firm returns respectively, controlling for various firm fundamentals. In column (1), we observe that the coefficient of COVID19 Case is highly significant and negative (at the 1\% level), indicating that the COVID-19 pandemic has exerted a significantly negative impact on Chinese real estate firm returns. We obtain similar results in column (2) with COVID19 Active Case as our variable of interest. The findings indicate that the COVID-19 pandemic has exerted a significant negative impact on real estate equities in China. For the control variables, we find that larger firms and firms with lower leverage ratios have higher firm returns. Moreover, firms with larger cash holdings have better firm returns. 
Table 2. Stock market returns during the COVID-19 pandemic.

\begin{tabular}{ccc}
\hline Variables & $\mathbf{( 1 )}$ & $\mathbf{( 2 )}$ \\
& Weekly Return & Weekly Return \\
\hline COVID19 Case & $\begin{array}{c}0.042^{* * *} \\
(-8.42)\end{array}$ \\
\hline COVID19 Active Case & & $-0.042^{* * *}$ \\
& & $(-8.45)$ \\
\hline Distance & 0.000 & 0.000 \\
Size & $(-0.18)$ & $(0.02)$ \\
\hline Leverage & $0.002^{*}$ & $0.002 *$ \\
& $(1.82)$ & $(1.76)$ \\
\hline \multirow{2}{*}{ Cash } & $-0.019^{*}$ & $-0.019 *$ \\
& $(-1.69)$ & $(-1.68)$ \\
\hline Intercept & $0.0240 *$ & $0.0240 *$ \\
& $(1.73)$ & -0.040 \\
\hline Property Type Fixed Effect & -0.040 & $(-1.25)$ \\
\hline Adjusted R-squared & $(-1.26)$ & Yes \\
\hline Observations & Yes & 0.054 \\
\hline
\end{tabular}

This table reports the results of regressing weekly stock returns on (1) the growth rate of COVID-19 cases and (2) the growth rate of active COVID-19 cases, controlling for firm fundamentals. The key independent variables of interest are COVID19 Case and COVID19 Active Case. $\mathrm{t}$-values are reported in the parentheses below the estimated coefficients. ${ }^{* * *}, * *$, and $*$ denote that the coefficients are statistically significant at the $1 \%, 5 \%$, and $10 \%$ levels, respectively. Variable definitions are provided in Appendix A.

In Table 3, we report our main empirical results of specifications (3) and (4), with the first and second columns showing the impact of the COVID-19 variables COVID19 Case and COVID19 Active Case on real estate firm returns respectively, controlling for geographic scope and various firm fundamentals. Once again, we observe that the COVID-19 pandemic exerts a significant negative impact on real estate firm returns, as the coefficients of the COVID-19 variables are statistically significant (at the $1 \%$ level) in both columns. Importantly, we also find that geographic scope imposes a mitigating effect on the pandemic, as the coefficients for the interaction terms of the COVID-19 variables and Geographic Scope are positively significant in both columns (at the $10 \%$ level). These results imply that returns of firms with broader geographic scope have decreased less from the pandemic. We attribute the findings to a diversified portfolio reducing the investors' perceived risk during the COVID-19 period when the virus spread was concentrated in several hard-hit regions in China. Economically, the coefficients of the interaction terms represent $13.55 \%$ of the main effects of the COVID-19 variables. Interestingly, we also find that the coefficients of Geographic Scope are insignificant, implying investors view geographic diversification as value-enhancing only at times of crises but not in the benchmark period. 
Table 3. Geographic scope and stock market returns during the COVID-19 pandemic.

\begin{tabular}{|c|c|c|}
\hline Variables & $\begin{array}{c}\text { (1) } \\
\text { Weekly Return }\end{array}$ & $\begin{array}{c}\text { (2) } \\
\text { Weekly Return }\end{array}$ \\
\hline COVID19 Case & $\begin{array}{c}-0.059 * * * \\
(-4.94)\end{array}$ & \\
\hline COVID19 Case ${ }^{*}$ Geographic Scope & $\begin{array}{l}0.008 * \\
(1.72)\end{array}$ & \\
\hline COVID19 Active Case & & $\begin{array}{c}-0.059^{* * *} \\
(-4.97)\end{array}$ \\
\hline COVID19 Active Case ${ }^{*}$ Geographic Scope & & $\begin{array}{l}0.008 * \\
(1.74)\end{array}$ \\
\hline Geographic Scope & $\begin{array}{c}0.000 \\
(0.15)\end{array}$ & $\begin{array}{l}0.001 \\
(0.18)\end{array}$ \\
\hline Distance & $\begin{array}{l}0.000 \\
(0.02)\end{array}$ & $\begin{array}{l}0.000 \\
(0.02)\end{array}$ \\
\hline Size & $\begin{array}{l}0.001 \\
(0.56)\end{array}$ & $\begin{array}{l}0.001 \\
(0.56)\end{array}$ \\
\hline Leverage & $\begin{array}{c}-0.019 * * \\
(-1.97)\end{array}$ & $\begin{array}{c}-0.019 \text { ** } \\
(-1.98)\end{array}$ \\
\hline Cash & $\begin{array}{l}0.022 * \\
(1.79)\end{array}$ & $\begin{array}{c}0.022^{* * *} \\
(2.80)\end{array}$ \\
\hline Intercept & $\begin{array}{l}-0.020 \\
(-0.40)\end{array}$ & $\begin{array}{l}-0.020 \\
(-0.40)\end{array}$ \\
\hline Property Type Fixed Effect & Yes & Yes \\
\hline Adjusted R-squared & 0.054 & 0.054 \\
\hline Observations & 1260 & 1260 \\
\hline
\end{tabular}

This table reports the results of regressing weekly stock returns and the interaction of the geographic scope of property allocations of real estate firms and (1) the growth rate of COVID-19 cases and (2) the growth rate of active COVID-19 cases, controlling for firm fundamentals. The key independent variables of interest are the interaction terms COVID19 Case ${ }^{*}$ Geographic Scope and COVID19 Active Case ${ }^{*}$ Geographic Scope. t-values are reported in the parentheses below the estimated coefficients. ${ }^{* * *}, * *$, and ${ }^{*}$ denote that the coefficients are statistically significant at the $1 \%, 5 \%$, and $10 \%$ levels, respectively. Variable definitions are provided in Appendix A.

\section{Heterogenous and Robustness Analysis}

\subsection{Heterogenous Analysis}

In additional heterogenous analysis, we examined if the importance of geographic scope varies for firms with different fundamentals. We conjecture that the moderating effect of geographic scope could hinge on how strong the firms were before the pandemic. On the one hand, firms with strong fundamentals going into the pandemic might suffer less from the COVID-19 crisis, and hence the role of geographic scope in mitigating the adverse impact of COVID-19 could be limited. On the other hand, firms with weak fundamentals pertain particularly to ongoing concern and business failure during the pandemic (Li et al. 2020). This could undermine the incremental importance of geographic scope in saving firms that are already deeply troubled.

To test our conjectures, we ran subsample regressions by partitioning our sample firms into two groups based on the median of Geographic Scope. Moreover, we included interactive terms of the COVID-19 variables with each of the firm fundamental variables (i.e., Distance, Size, Leverage, Cash) in the regressions. If geographic scope matters more to firms with stronger or weaker fundamentals, we expected differences in the coefficient estimates between the regressions for the subsamples of high versus low geographic scope. However, we offer no directional prediction as geographic scope can matter more or less for firms with stronger or weaker fundamentals. 
Table 4 reports the estimation results with columns (1), (2), (3), and (4) for the groups of high and low Geographic Scope. We find that the coefficients of the COVID-19 variables remain negative and significant (at the $10 \%$ level) in all columns. We also find that firms with higher leverage report lower returns during the COVID-19 period. The results are statistically significant (at the $5 \%$ or $10 \%$ levels) and persist in all columns, irrespective of the level of geographic scope. These findings imply that diversification does not serve as an effective corporate strategy to mitigate the negative impact due to COVID-19 on firm returns when firms are already highly leveraged.

Table 4. Heterogenous analysis of geographic scope and stock market returns during the COVID-19 pandemic.

\begin{tabular}{|c|c|c|c|c|}
\hline Variables & $\begin{array}{c}\text { (1) } \\
\text { Weekly Return }\end{array}$ & $\begin{array}{c}\text { (2) } \\
\text { Weekly Return }\end{array}$ & $\begin{array}{c}\text { (3) } \\
\text { Weekly Return }\end{array}$ & $\begin{array}{c}\text { (4) } \\
\text { Weekly Return }\end{array}$ \\
\hline & \multicolumn{2}{|c|}{ High Geographic Scope } & \multicolumn{2}{|c|}{ Low Geographic Scope } \\
\hline COVID19 Case & $\begin{array}{l}-0.330 * \\
(-1.79)\end{array}$ & & $\begin{array}{l}-0.303 * \\
(-1.83)\end{array}$ & \\
\hline COVID19 Case Distance & $\begin{array}{l}0.005 \\
(0.18) \\
\end{array}$ & & $\begin{array}{l}-0.022 \\
(-0.73)\end{array}$ & \\
\hline COVID19 Case*Size & $\begin{array}{l}0.012 * \\
(1.81)\end{array}$ & & $\begin{array}{l}0.015 \\
(1.22)\end{array}$ & \\
\hline COVID19 Case*Leverage & $\begin{array}{l}-0.077^{*} \\
(-1.694)\end{array}$ & & $\begin{array}{l}-0.069 * * \\
(-2.2915)\end{array}$ & \\
\hline COVID19 Case Cash & $\begin{array}{l}0.060 \\
(0.33)\end{array}$ & & $\begin{array}{l}0.034 \\
(0.45) \\
\end{array}$ & \\
\hline COVID19 Active Case & & $\begin{array}{l}-0.332 * \\
(-1.81)\end{array}$ & & $\begin{array}{l}-0.303 * \\
(-1.87)\end{array}$ \\
\hline COVID19 Active Case Distance & & $\begin{array}{l}0.005 \\
(0.19)\end{array}$ & & $\begin{array}{l}-0.022 \\
(-0.72)\end{array}$ \\
\hline COVID19 Active Case ${ }^{*}$ Size & & $\begin{array}{l}0.012 * \\
(1.82)\end{array}$ & & $\begin{array}{l}0.015 \\
(1.22)\end{array}$ \\
\hline COVID19 Active Case*Leverage & & $\begin{array}{l}-0.068 * \\
(-1.90)\end{array}$ & & $\begin{array}{l}-0.069 * * \\
(-2.16)\end{array}$ \\
\hline COVID19 Active Case Cash & & $\begin{array}{l}0.059 \\
(0.32)\end{array}$ & & $\begin{array}{l}0.035 \\
(0.46)\end{array}$ \\
\hline Distance & $\begin{array}{c}0.000 \\
(-0.93)\end{array}$ & $\begin{array}{l}-0.010 \\
(-0.93)\end{array}$ & $\begin{array}{l}0.000 \\
(0.94)\end{array}$ & $\begin{array}{l}0.000 \\
(0.94)\end{array}$ \\
\hline Size & $\begin{array}{l}0.000 \\
(0.06) \\
\end{array}$ & $\begin{array}{l}0.000 \\
(0.06) \\
\end{array}$ & $\begin{array}{l}0.003 \\
(0.87) \\
\end{array}$ & $\begin{array}{l}0.003 \\
(0.88)\end{array}$ \\
\hline Leverage & $\begin{array}{l}0.016 \\
(0.60)\end{array}$ & $\begin{array}{l}0.016 \\
(0.60)\end{array}$ & $\begin{array}{l}-0.022 \\
(-1.34)\end{array}$ & $\begin{array}{l}-0.022 \\
(-1.34)\end{array}$ \\
\hline Cash & $\begin{array}{l}0.020 \\
(0.30)\end{array}$ & $\begin{array}{l}0.020 \\
(0.30)\end{array}$ & $\begin{array}{l}0.021 \\
(0.83)\end{array}$ & $\begin{array}{l}0.021 \\
(0.83)\end{array}$ \\
\hline Intercept & $\begin{array}{l}-0.004 \\
(-0.08) \\
\end{array}$ & $\begin{array}{l}-0.005 \\
(-0.09) \\
\end{array}$ & $\begin{array}{l}-0.073 \\
(-0.84) \\
\end{array}$ & $\begin{array}{l}-0.074 \\
(-0.85) \\
\end{array}$ \\
\hline Property Type Fixed Effect & Yes & Yes & Yes & Yes \\
\hline Adjusted R-squared & 0.039 & 0.040 & 0.065 & 0.066 \\
\hline Observations & 684 & 684 & 576 & 576 \\
\hline
\end{tabular}

This table reports the results of regressing weekly stock returns and the interaction of firm characteristics and (1) the growth rate of COVID-19 cases and (2) the growth rate of active COVID-19 cases, controlling for firm fundamentals. Columns (1) and (2) report the results of the subsample of firms with high Geographic Scope, and columns (3) and (4) report the results of the subsample of firms with low Geographic Scope. The key independent variables of interest are all the interaction terms. $t$-values are reported in the parentheses below the estimated coefficients. ${ }^{* *}$ and ${ }^{*}$ denote that the coefficients are statistically significant at the $5 \%$ and $10 \%$ levels, respectively. Variable definitions are provided in Appendix A. 
The interaction terms of the COVID-19 variables and Size, on the other hand, are significantly positive for firms with high, but not those with low, Geographic Scope. These findings are interesting, as they imply that larger firms do not report better performance during the COVID-19 period unless they have adopted a corporate strategy of increased geographic scope by diversifying their asset allocations. While smaller firms might have greater difficulties in pursuing a geographically diversified portfolio, our findings indicate that larger firms that recognize the importance of diversification are viewed favorably by investors.

\subsection{Robustness Analysis}

We conducted two robustness tests, as reported in this section, to corroborate our main findings. First, our findings could be sensitive to the choice of our benchmark period. In our research design, we used the two-month period before the discovery of the first COVID-19 case in China as our benchmark period. We supplemented our main analysis with an alternative benchmark period based on the two-month period from April to May in 2020, after the full lifting of lockdown measures in Wuhan at the beginning of April. In columns (1) and (2) of Table 5, we report the estimation results of specifications (3) and (4), respectively, with this alternative sample. While we continue to observe the significant negative impact of COVID-19 (at the 1\% level), we show a stronger mitigating effect of Geographic Scope (at the 5\% level) than in the main analysis with the coefficients of the interaction terms representing $18.46 \%$ of the main effects.

Next, we examined firm abnormal returns, instead of dividend-adjusted firm returns, to account for the risk-adjusted performance of sample firms. We calculated abnormal returns, Abnormal Return, as the weekly stock return of a firm minus its beta times valueweighted market index returns from the market model (e.g., Lins et al. 2017), and we ran specifications (3) and (4) with abnormal returns as our dependent variable. Estimation results reported in columns (3) and (4) of Table 5 continue to show the mitigating impact of Geographic Scope on the COVID-19 variables.

Table 5. Robustness analysis of geographic scope and stock market returns during the COVID-19 pandemic.

\begin{tabular}{|c|c|c|c|c|}
\hline Variables & $\begin{array}{c}\text { (1) } \\
\text { Weekly Return }\end{array}$ & $\begin{array}{c}\text { (2) } \\
\text { Weekly Return }\end{array}$ & $\begin{array}{c}\text { (3) } \\
\text { Abnormal Return }\end{array}$ & $\begin{array}{c}\text { (4) } \\
\text { Abnormal Return }\end{array}$ \\
\hline COVID19 Case & $\begin{array}{c}-0.065 * * * \\
(-4.70)\end{array}$ & & $\begin{array}{c}-0.049 * * * \\
(-5.12)\end{array}$ & \\
\hline COVID19 Case* Geographic Scope & $\begin{array}{l}0.012 * \\
(1.85)\end{array}$ & & $\begin{array}{l}0.008 * \\
(1.89)\end{array}$ & \\
\hline COVID 19 Active Case & & $\begin{array}{c}-0.065^{* * *} \\
(-4.71)\end{array}$ & & $\begin{array}{c}-0.049 * * * \\
(-5.18)\end{array}$ \\
\hline COVID Active Case* Geographic Scope & & $\begin{array}{l}0.012 * \\
(1.83)\end{array}$ & & $\begin{array}{l}0.008 * \\
(1.94)\end{array}$ \\
\hline Geographic Scope & $\begin{array}{l}-0.004 \\
(-0.90)\end{array}$ & $\begin{array}{l}-0.004 \\
(-0.91)\end{array}$ & $\begin{array}{l}0.001 \\
(0.29)\end{array}$ & $\begin{array}{l}0.001 \\
(0.28)\end{array}$ \\
\hline Distance & $\begin{array}{c}0.000 \\
(-0.09)\end{array}$ & $\begin{array}{c}0.000 \\
(-0.10)\end{array}$ & $\begin{array}{l}0.000 \\
(0.07)\end{array}$ & $\begin{array}{l}0.000 \\
(0.07)\end{array}$ \\
\hline Size & $\begin{array}{l}0.002 \\
(0.52)\end{array}$ & $\begin{array}{l}0.002 \\
(1.49)\end{array}$ & $\begin{array}{l}0.001 \\
(0.65)\end{array}$ & $\begin{array}{l}0.001 \\
(0.65)\end{array}$ \\
\hline Leverage & $\begin{array}{l}-0.012 * \\
(-1.74)\end{array}$ & $\begin{array}{l}-0.012 * \\
(-1.73)\end{array}$ & $\begin{array}{c}-0.019 * * \\
(-1.98)\end{array}$ & $\begin{array}{l}-0.019 * \\
(-1.84)\end{array}$ \\
\hline Cash & $\begin{array}{l}0.011 \\
(1.36)\end{array}$ & $\begin{array}{l}0.011 \\
(1.38)\end{array}$ & $\begin{array}{l}0.023 * \\
(1.71)\end{array}$ & $\begin{array}{l}0.023 * \\
(1.72)\end{array}$ \\
\hline Intercept & $\begin{array}{l}-0.022 \\
(-0.32)\end{array}$ & $\begin{array}{l}-0.023 \\
(-0.33)\end{array}$ & $\begin{array}{l}-0.019 \\
(-0.46)\end{array}$ & $\begin{array}{l}-0.019 \\
(-0.46)\end{array}$ \\
\hline
\end{tabular}


Table 5. Cont.

\begin{tabular}{cccccc}
\hline Variables & $\mathbf{( 1 )}$ & (2) & (3) & (4) \\
& Weekly Return & Weekly Return & Abnormal Return & Abnormal Return \\
\hline Property Type Fixed Effect & Yes & Yes & Yes & Yes \\
\hline Adjusted R-squared & 0.051 & 0.052 & 0.054 & 0.054 \\
\hline Observations & 1260 & 1260 & 1260 & 1260 \\
\hline
\end{tabular}

This table reports the results of regressing weekly stock returns and the interaction of the geographic scope of property allocation of real estate firms and (1) the growth rate of COVID-19 cases and (2) the growth rate of active COVID-19 cases, controlling for firm fundamentals. Columns (1) and (2) consider the recovery period (April to May 2020) as the benchmark period, and columns (3) and (4) use the abnormal returns derived from the market model as the dependent variable. The key independent variables of interest are the interaction terms COVID19 Case ${ }^{*}$ Geographic Scope and COVID19 Active Case ${ }^{*}$ Geographic Scope. t-values are reported in the parentheses below the estimated coefficients. ${ }^{* * *}, * *$, and $*$ denote that the coefficients are statistically significant at the $1 \%, 5 \%$, and $10 \%$ levels, respectively. Variable definitions are provided in Appendix A.

\section{Concluding Remarks}

In this paper, we show the importance of geographic scope and diversification in mitigating the adverse impact of the COVID-19 pandemic for a sample of real estate firms in China. We focus on the Chinese setting, as the lockdown and subsequent lifting of the lockdown of Hubei province and the city of Wuhan provide us with a reliable identification of the period during which the country was most affected by the COVID-19 pandemic. Focusing on real estate firms also provides us with a straightforward methodology to measure their level of geographic scope as these firms are relatively transparent in their corporate diversification strategy. Utilizing hand-collected data on property locations of Chinese real estate firms, we show that, despite the COVID-19 pandemic exerting a significantly negative impact on real estate firm returns, geographic scope mitigates this negative impact during the pandemic. The findings imply that geographical diversification is useful in lessening the adverse impact brought upon by the current health crisis. Moreover, we show that firm size has a significant bearing on moderating the impact of COVID-19 but only when these larger firms also adopt a geographically diversified corporate strategy.

Overall, our findings quantify the impact of the COVID-19 pandemic in the Chinese real estate market and highlight the role of geographic scope and diversification at times of crises. While the COVID-19 pandemic has undoubtedly created an unprecedented crisis to the world and for the global stock markets, it is important to understand what factors could have made firms more resilient to such a crisis. Our study provides novel evidence of the benefit of geographic diversification during the COVID-19 health crisis, which should also give valuable insights into firms for weathering future crises.

Author Contributions: Data curation, X.C.; writing, D.T.; writing and reviewing, C.L. All authors have read and agreed to the published version of the manuscript.

Funding: This research received no external funding.

Institutional Review Board Statement: Not applicable.

Informed Consent Statement: Not applicable.

Data Availability Statement: The data used in this study can be found from China Stock Market and Accounting Research (CSMAR) database.

Conflicts of Interest: The authors declare no conflict of interest. 


\section{Appendix A}

Table A1. Variable definitions.

\begin{tabular}{|c|c|}
\hline Variables & Definitions \\
\hline Weekly Return & $\begin{array}{l}\text { The weekly stock return of a firm calculated by dividend-adjusted closing prices on the last trading day } \\
\text { of a week. }\end{array}$ \\
\hline Abnormal Return & The weekly stock return of a firm minus its beta times value-weighted market returns. \\
\hline COVID19 Case & 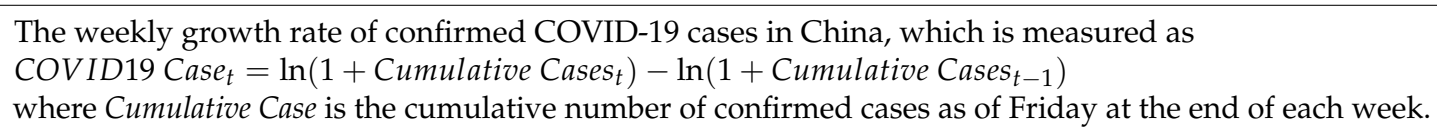 \\
\hline COVID19 Active Case & $\begin{array}{l}\text { The weekly growth rate of active COVID- } 19 \text { cases in China, which is measured by } \\
\text { COVID19 Active Case } \text { Cast }_{t} \ln (1+\text { Active Cases })-\ln (1+\text { Active Cases } \\
t-1) \\
\text { where Active Case is equal to Cumulative Case minus recoveries and death. }\end{array}$ \\
\hline Geographic Scope & The natural logarithm of the number of cities where a real estate firm has operations in 2019. \\
\hline Distance & $\begin{array}{l}\text { The natural logarithm of the distance between corporate headquarters location and the centroid } \\
\text { of Wuhan. }\end{array}$ \\
\hline Size & Firm size measured by the natural logarithm of total assets in 2019. \\
\hline Leverage & Total liabilities divided by total assets in 2019. \\
\hline Cash & The ratio of cash and cash equivalents to total assets in 2019. \\
\hline
\end{tabular}

\section{References}

Acharya, Viral, and Sascha Steffen. 2020. The risk of being a fallen angel and the corporate dash for cash in the midst of COVID. CEPR COVID Economics 10: 44-61.

Akinsomi, Omokolade. 2020. How resilient are REITs to a pandemic? The COVID-19 effect. Journal of Property Investment E Finance. forthcoming. [CrossRef]

Albuquerque, Rui, Yrjo Koskinen, Shuai Yang, and Chendi Zhang. 2020. Resiliency of environmental and social stocks: An analysis of the exogenous COVID-19 market crash. The Review of Corporate Finance Studies 9: 593-621. [CrossRef]

Alfaro, Laura, Anusha Chari, Andrew Greenland, and Peter Schott. 2020. Aggregate and Firm-Level Stock Returns during Pandemics, in Real Time. NBER Working Paper Series No. 26950. Available online: http:/ / www.nber.org/papers/w26095 (accessed on 11 September 2020).

Ayers, Benjamin, Santhosh Ramalingegowda, and Eric Yeung. 2011. Hometown advantage: The effects of monitoring institution location on financial reporting discretion. Journal of Accounting and Economics 52: 41-61. [CrossRef]

Baker, Scott, Nicholas Bloom, Steven Davis, Kyle Kost, Macro Sammon, and Tasaneeya Viratyosin. 2020. The unprecedented stock market reaction to COVID-19. The Review of Asset Pricing Studies 10: 742-58. [CrossRef]

Berger, Philip, and Eli Ofek. 1995. Diversification's effect on firm value. Journal of Financial Economics 37: 39-65. [CrossRef]

Boer, Dick, Dick Brounen, and Op't Hans Veld. 2005. Corporate focus and stock performance international evidence from listed property markets. The Journal of Real Estate Finance and Economics 31: 263-81. [CrossRef]

Campbell, Robert, Milena Petrova, and C. F. Sirmans. 2003. Wealth effects of diversification and financial deal structuring: Evidence from REIT property portfolio acquisitions. Real Estate Economics 31: 347-66. [CrossRef]

Capozza, Dennis, and Paul Seguin. 1998. Managerial style and firm value. Real Estate Economics 26: 131-50. [CrossRef]

Chakrabarti, Abhirup, Kulwant Singh, and Ishtiaq Mahmood. 2007. Diversification and performance: Evidence from East Asian firms. Strategic Management Journal 28: 101-20. [CrossRef]

Chen, Chen, Sudipto Dasgupta, Thanh Huynh, and Ying Xia. 2020. Were Stay-at-Home Orders during the COVID-19 Harmful for Business? - The market's View. Working Paper. Melbourne: Monash University, Hong Kong: Chinese University of Hong Kong.

Chu, Xiaoling, Desmond Tsang, and Siu Kei Wong. 2021. Geographic Diversification and Firm Performance: Where Firms Diversify Matter. Working Paper. Hong Kong: University of Hong Kong, Montreal: McGill University.

Cronqvist, Henrik, Peter Högfeldt, and Mattias Nilsson. 2001. Why agency costs explain diversification discounts. Real Estate Economics 29: 85-126. [CrossRef]

D'Lima, Walter, Luis Lopez, and Archana Pradhan. 2020. COVID-19 and Housing Market Effects: Evidence from U.S. Shutdown Orders. Working Paper. Norfolk: Old Dominion University.

Delios, Andrew, and Paul Beamish. 1999. Geographic scope, product diversification, and the corporate performance of Japanese firms. Strategic Management Journal 20: 711-27. [CrossRef]

Demirci, Irem, Piet Eichholtz, and Erkan Yönder. 2018. Corporate diversification and the cost of debt. The Journal of Real Estate Finance and Economics 61: 316-68. [CrossRef] 
Denis, David, Diane Denis, and Keven Yost. 2002. Global diversification, industrial diversification, and firm value. Journal of Finance 57: 1951-79. [CrossRef]

Ding, Haoyuan, Haichao Fan, and Shu Lin. 2020. COVID-19, Firm Exposure, and Firm Value: A Tale of Two Lockdowns. Working Paper. Shanghai: Shanghai University of Finance and Economics, Shanghai: Fudan University, Shanghai: Shanghai Institute of International Finance and Economics, Hong Kong: Chinese University of Hong Kong.

Ding, Wenzhi, Ross Levine, Chen Lin, and Wensi Xie. 2021. Corporate immunity to the COVID-19 pandemic. Journal of Financial Economics. forthcoming. [CrossRef]

Eichholtz, Piet, Martin Hoesli, Bryan MacGregor, and Nanda Nanthakumaran. 1995. Real estate portfolio diversification by property type and region. Journal of Property Finance 6: 39-59. [CrossRef]

Fahlenbrach, Rüdiger, Kevin Rageth, and René Stulz. 2020. How valuable is financial flexibility when revenue stops? Evidence from the COVID-19 crisis. The Review of Financial Studies. forthcoming. [CrossRef]

Feng, Zhilan, Maneechit Pattanapanchai, Mckay Price, and C. F. Sirmans. 2019. Geographic diversification in real estate investment trusts. Real Estate Economics. forthcoming. [CrossRef]

Gao, Wenlian, Lilian Ng, and Qinghai Wang. 2008. Does geographic dispersion affect firm valuation? Journal of Corporate Finance 14: 674-87. [CrossRef]

Grant, Robert, Azar Jammine, and Howard Thomas. 1988. Diversity, diversification, and profitability among British manufacturing companies. Academy of Management Journal 31: 771-801.

Hartzell, Jay, Libo Sun, and Sheridan Titman. 2014. Institutional investors as monitors of corporate diversification decisions: Evidence from real estate investment trusts. Journal of Corporate Finance 25: 61-72. [CrossRef]

Hashai, Niron. 2015. Within-industry diversification and firm performance-An S-shaped hypothesis. Strategic Management Journal 36: 1378-400. [CrossRef]

Hassan, Tarek Alexander, Stephan Hollander, Laurence van Lent, and Ahmed Tahoun. 2020. Firm-Level Exposure to Epidemic Diseases: COVID-19, SARS, and H1N1. NBER Working Paper Series No. 26971. Available online: http:/ /www.nber.org/papers/w26971 (accessed on 12 September 2020).

Hitt, Michael, Laszlo Tihanyi, Toyah Miller, and Brian Connelly. 2006. International diversification: Antecedents, outcomes, and moderators. Journal of Management 32: 831-67. [CrossRef]

$\mathrm{Hu}$, Maggie, Desmond Tsang, and Wayne X.inwei Wan. 2021. CEO Overconfidence and the COVID-19 Pandemic. Working Paper. Hong Kong: Chinese University of Hong Kong, Montreal: McGill University, Cambridge: University of Cambridge.

Huang, Naqun, Jindong Pang, and Yanmin Yang. 2020. The Impact of the COVID-19 Epidemic on the Housing Market in China. Working Paper. Nanjing: Nanjing Audit University, Wuhan: Wuhan University.

Lewellen, Wilbur. 1971. A pure financial rationale for the conglomerate merger. The Journal of Finance 26: 521-37. [CrossRef]

Li, Kai, Xing Liu, Feng Mai, and Tengfei Zhang. 2020. The Role of Corporate Culture in Bad Times: Evidence from the COVID-19 Pandemic. Working Paper. Vancouver: University of British Columbia, Hoboken: Stevens Institute of Technology, Baton Rouge: Louisiana State University.

Li, Rita Yi Man, XiaoGuang Yue, and James Crabbe. 2021. COVID-19 in Wuhan, China: Pressing realities and city management. Frontiers in Public Health 8: 596913. [CrossRef] [PubMed]

Ling, David, Chongyu Wang, and Tingyu Zhou. 2020. A first look at the impact of COVID-19 on commercial real estate prices: Asset level evidence. The Review of Asset Pricing Studies. forthcoming. [CrossRef]

Ling, David, Chongyu Wang, and Tingyu Zhou. 2021. The geography of real property information and investment: Firm location, asset location and institutional ownership. Real Estate Economics 49: 287-331. [CrossRef]

Lins, Karl, Henri Servaes, and Ane Tamayo. 2017. Social capital, trust, and firm performance: The value of corporate social responsibility during the financial crisis. Journal of Finance 72: 1785-824. [CrossRef]

Markides, Constantinos. 1995. Diversification, restructuring and economic performance. Strategic Management Journal 16: 101-18. [CrossRef]

Milcheva, Stanimira, Yildiray Yildirim, and Bi ng Zhu. 2020. Distance to Headquarter and Real Estate Equity Performance. The Journal of Real Estate Finance and Economics, 1-27. [CrossRef]

Pagano, Macro, Christian Wagner, and Josef Zechner. 2020. Disaster Resilience and Asset Prices. Working Paper. Naples: University of Naples Federico II.

Palich, Leslie, Laura Cardinal, and Chet Miller. 2000. Curvilinearity in the diversification-performance linkage: An examination of over three decades of research. Strategic Management Journal 21: 155-74. [CrossRef]

Papanikolaou, Dimitris, and Lawrence Schmidt. 2020. Working Remotely and the Supply-Side Impact of COVID-19. NBER Working Paper Series No. 27330. Available online: http:/ / www.nber.org/papers/w27330 (accessed on 10 September 2020).

Pettersson, Henrik, Byron Manley, and Sergio Hernandez. 2020. Tracking Coronavirus' Global Spread. CNN, September 29. Available online: https:/ / www.cnn.com/interactive/2020/health/coronavirus-maps-and-cases / (accessed on 29 September 2020).

Qian, Gongming, Lee Li, Ji Li, and Zhengming Qian. 2008. Regional diversification and firm performance. Journal of International Business Studies 39: 197-214. [CrossRef]

Qian, Gongming, Theodore Khoury, Mike Peng, and Zhengming Qian. 2010. The performance implications of intra-and inter-regional geographic diversification. Strategic Management Journal 31: 1018-30. [CrossRef] 
Qian, Xianhang, Shanyun Qiu, and Guangli Zhang. 2021. The impact of COVID-19 on housing price: Evidence from China. Finance Research Letters, 101944. [CrossRef]

Ramelli, Stefano, and Alexander Wagner. 2020. Feverish stock price reactions to COVID-19. The Review of Corporate Finance Studies 9: 622-55. [CrossRef]

Santalo, Juan, and Manuel Becerra. 2008. Competition from specialized firms and the diversification-performance linkage. Journal of Finance 63: 851-83. [CrossRef]

Schoenfeld, Jordan. 2020. The Invisible Risk: Pandemics and the Financial Markets. Working Paper. Hanover: Dartmouth College.

Shan, Chenyu, and Dragon Yongjun Tang. 2020. The Value of Employee Satisfaction in Disastrous Times: Evidence from COVID-19. Working Paper. Shanghai: Shanghai University of Finance and Economics.

Shehzad, Khurram, Liu Xiaoxing, and Hayfa Kazouz. 2020. COVID-19's disasters are perilous than global financial crisis: A rumor or fact? Finance Research Letters 36: 101669. [CrossRef]

Shi, Guifeng, Jianfei Sun, and Rui Luo. 2015. Geographic dispersion and earnings management. Journal of Accounting and Public Policy 34: 490-508. [CrossRef]

Singh, Bhanwar, Rosy Fhall, and Sahil Narang. 2020. The outbreak of COVID-19 and stock market responses: An event study and panel data analysis for G-20 countries. Global Business Review. [CrossRef]

Stein, J. C. 1997. Internal capital markets and the competition for corporate resources. Journal of Finance 52: 111-33. [CrossRef]

Sun, Yunchuan, Mengyuan Wu, Xiaoping Zeng, and Zihan Peng. 2021. The impact of COVID-19 on the Chinese stock market: Sentimental or substantial? Finance Research Letters 38: 101838. [CrossRef]

Tallman, Stephen, and Jiatao Li. 1996. Effects of international diversity and product diversity on the performance of multinational firms. Academy of Management Journal 39: 179-96.

Van, Dijk Dorinth, Anne Kinsella Thompson, and David Geltner. 2020. COVID-19 Special Report: Recent Drops in Market Liquidity May Foreshadow Major Price Drops in U.S. Commercial Real Estate Markets. Cambridge: MIT Center for Real Estate.

Xie, Lingshan, and Stanimira Milcheva. 2020. Proximity to COVID-19 Cases and Real Estate Equity Returns. Working Paper. London: University College London.

Yang, Minhua, and Junni Zhou. 2021. The impact of COVID-19 on the housing market: Evidence from the Yangtze River delta region in China. Applied Economics Letters. [CrossRef]

Zhao, Yunhui. 2020. U.S. Housing Market during COVID-19: Aggregate and Distributional Evidence. Working Paper. Washington, DC: IMF. 